\title{
Unfolding Water Quality Status During COVID-19 Lockdown for the Highly Polluted Santiago River in Jalisco, Mexico
}

Gurusamy Kutralam-Muniasamy

CINVESTAV IPN: Centro de Investigacion y de Estudios Avanzados del Instituto Politecnico Nacional

Fermín Pérez-Guevara

CINVESTAV IPN: Centro de Investigacion y de Estudios Avanzados del Instituto Politecnico Nacional

Ignacio Elizalde Martinez

IPN: Instituto Politecnico Nacional

Shruti Venkata Chari ( $\nabla$ shrutifrnd@gmail.com )

UNAM IGI: Universidad Nacional Autonoma de Mexico Instituto de Geologia

\section{Research Article}

Keywords: Water pollution, DO, COD, BOD, Arsenic, Lead.

Posted Date: November 10th, 2021

DOI: https://doi.org/10.21203/rs.3.rs-581075/v2

License: () (1) This work is licensed under a Creative Commons Attribution 4.0 International License. Read Full License 


\section{Abstract}

The Santiago River is one of Mexico's most polluted waterways and evaluating its surface water quality during the COVID-19 outbreak is critical to assessing the changes and improvements, if any, from the nationwide lockdown (April-May 2020). Hence, the data for 12 water quality parameters from 13 sampling stations during April-May 2020 (lockdown) were compared with the levels for the same period of 2019 (pre-lockdown) and with the same interval of previous eleven-years (2009-2019). The values of BOD (14\%), COD (29\%), TSS (7\%), f. coli (31\%), t. coli $(14 \%)$ and $\mathrm{Pb}(20 \%)$ declined, while pH, EC, turbidity, total nitrogen and As enhanced by $0.3-21 \%$ during the lockdown compared to the pre-lockdown period suggesting decrements of organic load in the river due to the temporary closure of industrial and commercial activities. An eleven-year comparison estimated the reduction of $\mathrm{pH}, \mathrm{TSS}, \mathrm{COD}$, total nitrogen and $\mathrm{Pb}$ by 1 $38 \%$. The analysis of water quality index estimates showed short-term improvements of river water quality in the lockdown period, compared to pre-lockdown and eleven-year trend as well as indicated very poor quality of the river. The contamination sources identified by factor analysis were mainly related to untreated domestic sewage, industrial wastewaters and agriculture effluents influencing the river water quality. Overall, our findings demonstrated positive responses of COVID-19 imposed lockdown on water quality of the Santiago River during the study period, providing a foundation for the government policy makers to identify the sources of pollution, to better design environmental policies and plans for water quality improvements.

\section{Introduction}

Since late 2019, COVID-19 disease caused by novel coronavirus (SARS-CoV-2) continues to prevail in more than 210 countries and represents a global health crisis. On October 27, 2020, the total number of confirmed cases were over 43 million and the death toll exceeded 1 million worldwide (WHO 2020). Due to COVID-19 pandemic, almost all affected countries adopted dramatic measures and imposed voluntary lockdowns to maintain social distancing, restrict public gatherings and successfully slowed COVID-19 trends. Mexico is one of the most affected countries by COVID-19 and ranks four in terms of death toll next to United States, Brazil, and India. The first case of COVID-19 was detected in Mexico on February 27, 2020, and by March 17, 2020, all 32 federal states of Mexico presented COVID-19 cases (Mexico Health Ministry 2020). On March 31, Mexican health authorities declared the nationwide health emergency imposing the first partial lockdown until April 30 (GDF 2020). After its success, the government extended the restriction by imposing the second period of lockdown until May 31, accounting for a total of 62 days of lockdown across Mexico during COVID-19 pandemic. The lockdown measures included, prohibiting movements of human beings by restricting large-scale private and public social gatherings, public transportation and even by shutting down schools and suspending industrial activities.

Increased industrialization and anthropogenic activities are recognized to be the most important factors of pollution within diverse environmental compartments. With the significant strict restrictions of human movement and industrial shutdowns, the researchers and policy makers took this small window of opportunity to quantify the status of pollution during the lockdown period, to understand the effect of the COVID-19 measures on the environment and to gain insights for the short- and long-term implementations. At this critical time, a number of articles has recorded and provided evidence for the decrements of various types of pollution and environmental restoration worldwide. In particular, the drop in regional traffic, along with reduced industrial and commercial activities, shown a significant reduction of many air-pollutants across several nations (Kutralam-Muniasamy et al. 2020; Otmani et al. 2020; Nakada and Urban, 2020; Gautam, 2020). The significant improvements in the water quality of lake (Yunus et al. 2020), river (Patel et al. 2020; Dutta et al. 2020), groundwater (Selvam et al. 2020) and canal (Saadat et al. 2020) were also observed in several locations around the world. Moreover, the noise pollution reduction as well as a possible positive effect on wildlife and the ecosystem is also highly expected. Thus, it can be said with certainty that despite all the negative impacts of COVID-19 pandemic, the temporary shutdown has created a positive impact on environment in many parts of the world, leaving footprints to learn towards future policies and environmental planning.

Till date, very few studies have examined the changes in water quality during the COVID-19 lockdown period. Recognizing the observed positive changes, in this study, we focus our attention on Santiago River (Jalisco) which is one of the highly polluted rivers in Mexico, where the water pollution has been greatly affected by urban expansion, industrialization and other human-induced actions over decades (McCulligh et al. 2007; Rizo-Decelis and Andreo, 2016; McCulligh and Vega Fregoso, 2019). We hypothesis that the nationwide lockdown enforced in Mexico would have reduced the discharges of untreated industrial wastewater and sewage into the river and as a result, we can expect weakening of pollutants load possibly leading to improvement in water quality, at least temporarily, as observed in other regions. At the same time, it remains to be investigated to what degree the lockdown measures and reduced anthropogenic activities impact the water quality of Santiago River amid the COVID-19 pandemic. Hence the present work was

Page 2/15 
undertaken to look at how the lockdown affected water quality status and improved, if any, in Santiago River using a combination of 12 measured parameters, including: - $\mathrm{pH}$, conductivity (EC), turbidity, total suspended solids (TSS), dissolved oxygen (DO), biological oxygen demand (BOD), chemical oxygen demand (COD), total nitrogen (TN), faecal coliform (f. coli), total coliform (t. coli) as well as heavy metals such as arsenic (As) and lead (Pb) for the period of April 1 to May 31, 2020. In this regard, we assessed water quality during the lockdown by estimating the changes observed in 12 parameters between the lockdown (April 1 - May 31, 2020) and prelockdown (April 1 - May 31, 2019) periods, as well as by comparing the water quality data of lockdown period with the same interval of previous eleven-years (2009-2019). Furthermore, factor analysis was applied for the identification of the possible sources influencing the river system as well the water quality index was estimated to determine the actual water quality status of the Santiago River. Taking together, we believe that the findings of this study would shed light on the implications of COVID-19 measures on river water pollution in Mexico and help to examine the changes caused by lockdown in our environmental system.

\section{Methodology}

\subsection{Study area and sampling sites}

Santiago River basin, with an extension of $76.749 \mathrm{~km}^{2}$ located in central west Mexico (23 $24^{\prime} 36^{\prime \prime}$ and $20^{\circ} 18^{\prime} 03^{\prime \prime} \mathrm{N}, 101^{\circ} 16^{\prime} 48^{\prime \prime}$ and $105^{\circ} 28^{\prime} 12^{\prime \prime} \mathrm{W}$ ), and forms part of the Lerma-Chapala-Santiago hydrological basin. Being one of the longest rivers in Mexico, Santiago River begins at Chapala Lake in Jalisco state and traverses $475 \mathrm{~km}$ through six states namely, Durango, Zacatecas, Aguascalientes, Guanajuato, Jalisco, and Nayarit flowing into the Pacific Ocean. It's primary tributary is the Lerma River which receives several wastewater discharges from the densely populated metropolitan area of the State of Mexico, and surrounding cities (Fig. 1). Also, it receives waters from several other rivers such as Verde, Juchipila, Bolaños and Zula joining at several locations. The delimitation of the study area was considered from the origin of the Santiago River (Chapala Lake) and up to border of Jalisco before entering the state of Nayarit (Fig. 1). This river basin experiences dry and warm climate with a mean temperature of $19.3^{\circ} \mathrm{C}$ and precipitation rate of $736 \mathrm{~mm} \mathrm{year}^{-1}$ (INEGI 2014). On the geological front, the river basin is bounded by the Sierra Madre Occidental on the NW-NE and by the Trans-Mexican Volcanic Belt on SE-NE. The Cenozoic extrusive igneous rocks of Tertiary age overlaid with lower proportion of alluvial materials of Tertiary and Quaternary age prevail in this basin (Ferrari et al. 2012). In addition, Mesozoic sedimentary rocks from Cretaceous are also found in this basin, but to a lesser extent (Ferrari et al. 2012).

Santiago River flows through Jalisco with an approximate route of $262.5 \mathrm{~km}$ length, crossing municipalities of Ocotlán, Poncitlán, Atequiza, Atotonilquillo, Juanacatlán, El Salto, Tonalá and among others. The population in Santiago River basin is estimated to be approximately 7.5 million inhabitants with 4.8 million concentrated in Guadalajara City (INEGI 2015). It has been a backbone of economic growth in Jalisco, once a tourist attraction, a source of clean drinking water supporting nearly $70 \%-80 \%$ of the water needs in its urban area (Guadalajara) and is now heavily contaminated (Von Bertrab 2003; Ochoa and Bürkner, 2012; Rizo-Decelis and Andreo, 2016; McCulligh and Vega Fregoso, 2019). It receives discharges of more than 300 industries belonging to aluminium, plastic, paper, chemical and petrochemical, automotive, food and beverages in the Ocotlán-El Salto and Guadalajara industrial corridor through the El Ahogado and Arroyo Seco channels (McCulligh et al. 2007; McCulligh and Vega Fregoso, 2019). The rapid growth of the population in this metropolis (10 times in 65 years), coupled with urbanization, and industrialization with inadequate land-use planning and untreated wastewater, has deteriorated the water quality of Santiago River. Due to the presence of toxic substances such as cadmium, chromium, arsenic, and lead in Santiago River from industrial dumping, it is classified as one of the most polluted waterways in Mexico. Thus, exploring water quality of Santiago River under COVID-19 lockdown is an ideal opportunity to give us an unprecedented glimpse into what happens on the river system when the human activities are drastically reduced.

\subsection{Monitoring stations and data collection}

Owing to the exacerbating contamination problem, Jalisco State Water Commission (CEA) established monthly monitoring campaigns since 2009 in 13 locations along the river course to analyze and record physical, chemical and biological characteristics of river waters. The monitoring stations are located in the first $262.5 \mathrm{~km}$ stretch of Santiago River from Chapala Lake within Jalisco state (Fig. 1). The stations 1-10 are located along the river course among which stations 4-7 lie in the metropolitan area. The stations 11 and 12 correspond to El Ahogado canal and station 13 to Zula River. To quantify the levels of physiochemical and biological characteristics and heavy metals, CEA collect monthly water samples at each station in triplicate and analyzed in the laboratories certified by the Mexican Accreditation Entity (EMA), in accordance with the national official Mexican Standard Norm NMX-EC717025-IMNC-2006. For this study, the data generated in the monthly monitoring carried out by CEA (http://www.ceajalisco.gob.mx/contenido/datos_abiertos/) seems to be an excellent source of information and the available dataset

Page 3/15 
provides us a unique opportunity to study the water quality of the Santiago River before (April-May 2019) and during the lockdown (April-May 2020) as well as for understanding its evolution in eleven-year period (2009-2019). Data for 12 characteristics including, physiochemical ( $\mathrm{pH}, \mathrm{EC}$, turbidity, TSS, DO, BOD, COD and TN), biological (f. coli and t. coli) and heavy metals (As and Pb) was obtained for the period of April and May months of 2009-2020.

\subsection{Surface water quality}

The surface water quality of Santiago River was evaluated through Water Quality Index (WQI) proposed by Horton (1965) and developed by Brown et al. (1970) and Cude (2001) which can provide a simple indicator of water quality for drinking purposes based on few important parameters. For this purpose, 6 parameters namely: $\mathrm{pH}, \mathrm{EC}, \mathrm{DO}, \mathrm{BOD}, \mathrm{COD}$ and TSS for 13 monitoring stations were used for the calculation of WQI by the following equations:

$$
\begin{gathered}
Q_{i}=\frac{\left(M_{i}-l_{i}\right)}{\left(S_{i}-l_{i}\right)} \times 100 \\
W_{i}=k / S_{i} \\
W Q I=\frac{\sum_{i=1}^{n} W_{i} Q_{i}}{\sum_{i=1}^{n} W_{i}}
\end{gathered}
$$

where,

$Q_{i}=$ sub-index of the ith parameter

$M_{i}=$ monitored value of the parameter

$\mathrm{I}_{\mathrm{i}}=$ ideal value; the ideal value for $\mathrm{pH}=7, \mathrm{DO}=14.6 \mathrm{mg} / \mathrm{l}$, and for other parameters it was considered equal to zero (Tripaty and Sahu, 2005; Chowdhury et al. 2012; Ewaid and Abed, 2017)

$\mathrm{S}_{\mathrm{i}}=$ standard value of the ith parameter; the values recommended by Mexican Standard Norm (2015) and World Health Organization (WHO, 2011)

$\mathrm{W}_{\mathrm{i}}=$ unit weightage of the ith parameter, calculated by the value inversely proportional to the standard value $\left(\mathrm{S}_{\mathrm{i}}\right)$ mentioned by Mexican Standard Norm (2015) and WHO (2011)

$\mathrm{n}=$ number of parameters included

Based on the calculated WQI, the category of water quality types is recognized as follows: excellent (0-25), good (26-50), poor (51-75), very poor (76-100) and unsuitable for drinking (>100).

\subsection{Statistics}

Statistica software version 8.0 was used for carrying out the statistical analysis of the data obtained. Factor analysis (FA) was performed using normalized variables for 12 parameters and eigenvalue $>1$ was taken as criterion for the extraction of the factors required for explaining the sources of variances in the data. Statistical analysis of water quality parameters in this study was conducted to see the interrelationship between different variables, to identify probable source in order to explain the contamination status of Santiago River and to observe the influence of restricted human activities over water quality during COVID-19 lockdown. Also, we performed correlation tests $(p<0.05,0.01$ and 0.001$)$ for the lockdown period to determine the relationship between the water quality parameters.

\section{Results And Discussion}

The observed trends (pre-lockdown, lockdown and eleven-year trend) of pH, EC, turbidity, TSS, DO, BOD, COD, TN, f. coli, t. coli, As and $\mathrm{Pb}$ at different locations throughout the stretch of the Santiago River are shown Fig. 2. The summary of the range, average value, 
measured variables in the river water samples between lockdown and pre-lockdown period, and the Mexican Standard Norm (2015) are provided in Table 1.

Table 1

Analytical data of water quality parameters during pre-lockdown and lockdown period at different locations of the Santiago River.

\begin{tabular}{|c|c|c|c|c|c|c|c|c|c|}
\hline \multirow{2}{*}{ Stations } & \multirow[b]{2}{*}{ Parameters } & \multicolumn{3}{|c|}{ Pre- lockdown } & \multicolumn{3}{|c|}{ Lockdown } & \multirow{2}{*}{$\begin{array}{l}\text { Relative } \\
\text { change } \\
\text { (\%) }\end{array}$} & \multirow{2}{*}{$\begin{array}{l}\text { Mexican } \\
\text { permissible } \\
\text { limits }\end{array}$} \\
\hline & & Min & Max & Average & Min & Max & Average & & \\
\hline 1 & $\mathrm{pH}$ & 7.1 & 9.4 & 7.738 & 6.6 & 9.1 & 7.762 & +0.30 & $6.5-8.5$ \\
\hline 2 & $\begin{array}{l}\text { Conductivity } \\
\text { (uS/cm) }\end{array}$ & 408 & 1745 & 1187.308 & 852 & 1957 & 1220.077 & +2.76 & - \\
\hline 3 & $\mathrm{DO}(\mathrm{mg} / \mathrm{L})$ & 0.08 & 8.95 & 3.778 & 0.02 & 6.98 & 3.368 & -10.84 & 5 \\
\hline 4 & $\begin{array}{l}\text { Turbidity } \\
\text { (NTU) }\end{array}$ & 408 & 1873 & 1187.308 & 464 & 1957 & 1220.077 & +2.76 & 3 \\
\hline 5 & TSS (mg/L) & 7 & 370 & 38.385 & 7 & 245 & 35.769 & -6.81 & 50 \\
\hline 6 & BOD (mg/L) & 2.03 & 425 & 46.208 & 2.09 & 183.61 & 39.866 & -13.72 & 30 \\
\hline 7 & COD (mg/L) & 16.52 & 997.78 & 150.355 & 19.68 & 388.6 & 106.028 & -29.48 & 40 \\
\hline 8 & $\begin{array}{l}\text { f. coli } \\
\text { (MPN/100 } \\
\text { mL) }\end{array}$ & 90 & $110,000,000$ & 12238289 & 40 & $46,000,000$ & 8422265 & -31.18 & 1000 \\
\hline 9 & $\begin{array}{l}\text { t. coli } \\
\text { (MPN/100 } \\
\text { mL) }\end{array}$ & 230 & $110,000,000$ & 12296617 & 70 & $46,000,000$ & 10545466 & -14.24 & - \\
\hline 10 & $\begin{array}{l}\text { Total } \\
\text { nitrogen } \\
(\mathrm{mg} / \mathrm{L})\end{array}$ & 0.96 & 69.74 & 17.095 & 0.42 & 52.95 & 18.211 & +6.52 & - \\
\hline 11 & As (mg/L) & 0.005 & 0.0148 & 0.008 & 0.0053 & 0.0146 & 0.010 & +20.98 & 0.01 \\
\hline 12 & $\mathrm{~Pb}(\mathrm{mg} / \mathrm{L})$ & 0.0072 & 0.0378 & 0.012 & 0.008 & 0.0141 & 0.010 & -19.76 & 0.01 \\
\hline
\end{tabular}

\subsection{Physiochemical characteristics}

The range of $\mathrm{pH}$ was similar in pre-lockdown (7.1-9.4) and lockdown (6.6-9.1) (Table 1 and Fig. 2). Only a marginal increase of $0.30 \%$ and decrease of $1.16 \%$ was noted during lockdown in relation to pre-lockdown and eleven-year trend. Owing to the smaller variations between pre-lockdown and lockdown along the river course, data on $\mathrm{pH}$ serves much less in identifying possible pollution sources and do not generate essential information on water quality. As shown in Fig. 2, high levels of EC were observed in all stations of Santiago River, with an increase of $2.76 \%$ during lockdown period compared to pre-lockdown period (Table 1). Similarly, the EC values showed a slight escalation of $2.43 \%$ between lockdown and eleven-year trend (Table 2). The reasons can be found when analyzing the changes of EC levels registered among the stations. In the study area, we observed the increase of 3.76\% in the metropolitan area (stations 4-7) indicating the augmentation of household wastes and waste disposal in the metropolitan area. More importantly, a decline of $5.56 \%$ in EC values was noted during lockdown in the sampling stations located at El Ahogado canal (11 and 12), which are greatly and usually affected by nearly 157 industrial wastewater discharges (Arellano-Aguilar et al. 2012; Ochoa and Bürkner, 2012; McCulligh and Vega Fregoso, 2019). This positive decline points out significant reduction in the industrial discharges of untreated wastewaters in proximate of El Ahogado canal as a consequence of lockdown measures. 
Table 2

Relative change of water quality parameters in Santiago River (Mexico) between the lockdown and eleven-years data.

\begin{tabular}{|lllll|}
\hline Stations & Parameters & $\mathbf{2 0 0 9 - 2 0 1 9}$ & $\mathbf{2 0 2 0}$ & Change (\%) \\
\hline 1 & pH & 7.853 & 7.762 & -1.16 \\
\hline 2 & Conductivity (uS/cm) & 1191.111 & 1220.077 & +2.43 \\
\hline 3 & DO (mg/L) & 3.114 & 3.368 & +8.16 \\
\hline 4 & Turbidity (NTU) & 1187.308 & 1220.077 & +2.76 \\
\hline 5 & TSS (mg/L) & 51.813 & 35.769 & -30.97 \\
\hline 6 & BOD (mg/L) & 33.500 & 39.866 & +19.00 \\
\hline 7 & COD (mg/L) & 124.236 & 106.028 & -14.66 \\
\hline 9 & f. coli (MPN/100 mL) & 2512287 & 8422265 & +235.24 \\
\hline 10 & t. coli (MPN/100 mL) & 3047798 & 10545466 & +246.00 \\
\hline 11 & TN (mg/L) & 19.745 & 18.211 & -7.77 \\
\hline 12 & As (mg/L) & 0.007 & 0.010 & +42.86 \\
\hline
\end{tabular}

The BOD and COD values were considerably diminished during the lockdown in comparison to their respective pre-lockdown levels (Table 1). Their mean concentrations reduced by $13.72 \%$ and $29.48 \%$ in lockdown. More notably, the stations located at metropolitan area and El Ahogado canal displayed significant reductions (20\% and $32 \%$ ) of COD. Despite of the reduced levels of BOD and COD, nearly $30-76 \%$ of stations exceeded the permissible limits of Mexican Standard Norm (BOD=30 mg/L; COD $=40 \mathrm{mg} / \mathrm{L}$ ). In relation to eleven-year trend, BOD increased by $19 \%$ and COD decreased by $14.66 \%$ during lockdown. There has been an increment of $6.52 \%$ and decrement of $7.77 \%$ in TN values during lockdown in relation to pre-lockdown period and eleven-year trend (Table 1 and 2). Generally, TN and BOD concentrations express the state of organic load, whereas COD levels reflect the trends of chemical contamination in a river system. As shown in Table 3, the significant correlations among BOD vs COD $\left(r^{2}=0.95\right)$ and TN $\left(r^{2}=0.88\right)$ indicates a common source of origin. In Santiago River, the organic and chemical loads mainly come from: (1) untreated gray water flow, (2) runoff from agricultural areas that carry excesses of nitrogen and phosphorous fertilizers and various agrochemicals (insecticides, fungicides, pesticides, etc.); and (3) industrial wastewater discharges, such as the stillage produced during the manufacture of beverages such as tequila and other industries that discharge organic waste into this river (McCulligh et al. 2007; Rizo-Decelis and Andreo, 2015; McCulligh and Vega Fregoso, 2019). From our results, it is highlighted that the diminished industrial activities during lockdown must have resulted in a notable level of reductions in BOD and COD, whereas agricultural activities that remained active might have contributed largely to increased TN levels. 
Table 3

Correlation between water quality parameters during lockdown period in Santiago River (Jalisco), Mexico.

\begin{tabular}{|c|c|c|c|c|c|c|c|c|c|c|c|c|}
\hline Parameters & $\mathrm{pH}$ & EC & DO & Turb & TSS & BOD & COD & f. coli & t. coli & $\mathrm{TN}$ & As & $\mathrm{Pb}$ \\
\hline $\mathrm{pH}$ & 1.00 & & & & & & & & & & & \\
\hline EC & - & 1.00 & & & & & & & & & & \\
\hline DO & $0.74^{\star \star}$ & - & 1.00 & & & & & & & & & \\
\hline Turb & - & 1.00 & - & 1.00 & & & & & & & & \\
\hline TSS & - & - & - & - & 1.00 & & & & & & & \\
\hline BOD & - & $0.67^{*}$ & $-0.59^{*}$ & $0.67^{*}$ & $0.80^{\star \dagger}$ & 1.00 & & & & & & \\
\hline COD & - & $0.61^{*}$ & $-0.59^{*}$ & $0.61^{*}$ & $0.82^{\star \star \ddagger}$ & $0.95^{\star \dagger \neq}$ & 1.00 & & & & & \\
\hline f. coli & - & - & - & - & - & - & $0.62^{*}$ & 1.00 & & & & \\
\hline t. coli & - & $0.61^{\star}$ & - & $0.61^{*}$ & - & $0.73^{*+}$ & $0.78^{\star+}$ & $0.95^{\star \star \ddagger}$ & 1.00 & & & \\
\hline TN & - & $0.80^{\star}+$ & - & $0.80^{\star}+$ & $0.73^{\star \dagger}$ & $0.87^{\star \ddagger \ddagger}$ & $0.88^{\star \star \ddagger}$ & $0.73^{\star \dagger}$ & $0.85^{\star \star \ddagger}$ & 1.00 & & \\
\hline As & - & - & - & - & - & - & - & - & - & - & 1.00 & \\
\hline $\mathrm{Pb}$ & - & - & - & - & $0.88^{\star \star \ddagger}$ & $0.77^{\star \dagger}$ & $0.83^{\star \star \ddagger}$ & - & $0.61^{*}$ & $0.85^{\star \star \ddagger}$ & - & 1.00 \\
\hline
\end{tabular}

The DO concentrations remained below $5 \mathrm{mg} / \mathrm{L}$ that does not meet the permissible limits in majority of the stations for all the three assessment periods (pre-lockdown, lockdown and eleven-year trend) (Fig. 2). DO values decreased by $10.84 \%$ and increased by $8.16 \%$ in lockdown with respect to pre-lockdown and eleven-year trend (Table 1 and 2). The low DO values suggest poor water quality and thereby, lack of oxygen in the water that have a negative impact on aquatic life. Maximum range $(4 \%-93 \%)$ of decreased DO levels were observed in the stations located at metropolitan area characterized with increased BOD levels. The correlation analysis demonstrated a negative relationship of DO with BOD $\left(r^{2}=-0.59\right)$ signifying that higher rate of bacterial decomposition of organic matter in the surface waters may have increased the demand of oxygen for their metabolic activities (Susilowati et al. 2018) and consequently, reduced the DO levels. Thus, the reductions in DO levels during lockdown in majority of the stations may be explained by the increment in BOD levels in those stations for the same period.

The values for turbidity in Santiago River for all the three assessment periods (pre-lockdown, lockdown and eleven-year trend) presented extremely higher orders of magnitude (>300 times) with respect to permissible limits of 3 NTU set by Mexican Standard Norm (2015) (Fig. 2). The lockdown period displayed an increment of $2.76 \%$ in turbidity values compared to both pre-lockdown and eleven-year trend. The correlation analysis showed a strong association of turbidity with TN $\left(r^{2}=0.80\right)$ suggesting the slight increment in values linked to agricultural effluents. The TSS values on the other hand showed reductions of $6.81 \%$ and $30.97 \%$ in lockdown when compared to pre-lockdown and eleven-year trend (Fig. 2). The strong relationship of TSS with BOD $\left(r^{2}=0.80\right)$ and COD $\left(r^{2}=0.80\right)$ signifies that the decrease in TSS during lockdown period may be associated with lower BOD and COD values due to attenuated industrial activities.

\subsection{Biological parameters}

The trend of $\mathrm{f}$. coli and t. coli counts in Santiago River water at the 13 sampling sites for three study periods is shown in Fig. 2. From our results, on one hand, the detection of $f$. coli throughout the stretch suggested the source of fecal contamination in the study area. It was previously reported that the entry of fecal matter is common and constant in the Santiago River (McCulligh et al. 2007; McCulligh and Vega Fregoso, 2019). Furthermore, untreated domestic sewages have been the main source of coliform bacteria, with other sources being direct discharge of waste from polluted irrigation water and storm runoff (Rodríguez-Tapia and Morales-Novelo, 2017; Seo et al. 2019). With the water of the Santiago River receiving constant fecal matter and exceeding Mexican Standard Norm (2015) permanently, it is an indicator for the presence of other disease-causing pathogenic bacteria and fungi that can impact human 
health coming into contact. Moreover, the intensive development of the metropolitan and industrial infrastructure could have added additional burden on the quality of river water. On the other hand, almost $90 \%$ of the stations reported higher concentrations of both $\mathrm{f}$. coli and t. coli exceeding multiple folds of WHO (500 MPN/100 mL) and Mexican Standard Norm (1000 MPN/100 mL).

The monitored concentrations of $\mathrm{f}$. coli in water samples ranged between 135 and $24200000 \mathrm{MPN} / 100 \mathrm{~mL}$ during lockdown period, whereas it was ranged from 160 to $78000000 \mathrm{MPN} / 100 \mathrm{~mL}$ in pre-lockdown period (Table 1). Whereas the t. coli counts were found between 150-25000000 MPN/100 mL and 230-55023000 MPN/100 mL during lockdown and pre-lockdown period. The results showed that t. coli counts reduced by approximately $14.24 \%$ from 12296617 to $10545466 \mathrm{MPN} / 100 \mathrm{~mL}$ in $50 \%$ of sampled stations between the lockdown and pre-lockdown period. Similarly, the contents of $\mathrm{f}$. coli declined sharply by $31.18 \%$ from 12238289 to $8422265 \mathrm{MPN} / 100 \mathrm{~mL}$ in 7 out of 13 stations during the lockdown and pre-lockdown period. In particular, a significant reduction of $20 \%$ of coliform bacteria (f. coli and t. coli) was recorded in the stations located at El Ahogado canal. These observations clearly indicate the reduced inflow of industrial effluents during lockdown and further confirmed by the strong positive associations of coliform bacteria with industrial organic pollutants like $\operatorname{BOD}\left(r^{2}=-; 0.73\right)$ and $\operatorname{COD}\left(r^{2}=0.62 ; 0.78\right)$. However, variations in the relative change of coliform bacteria were opposite when compared to eleven-year trend. Both coliforms augmented four times during lockdown compared to eleven-year trend (Table 2). This makes clear that although the coliform bacteria concentration fluctuated between lockdown and pre-lockdown period, it was generally in an upward trend over the decade. As seen in Table 3, the observed no associations of $\mathrm{pH}$ and DO with coliforms in the Santiago River which appeared to be a natural process due to the coliform bacteria proliferation and the occurrence of carbon dioxide (Seo et al. 2019). Nonetheless, the high concentrations of coliform pointed out the potential health threats from water-borne diseases and the immediate need for coliform management in the study area.

\subsection{Metals}

The concentrations of $\mathrm{As}$ and $\mathrm{Pb}$ showed significant variations in the lockdown period with respect to pre-lockdown and eleven-year trend (Fig. 2; Table 1 and 2). When we look at the As levels, it increased from $0.008 \mathrm{mg} / \mathrm{L}$ in pre-lockdown to $0.010 \mathrm{mg} / \mathrm{L}$ during lockdown accounting for $20.98 \%$ increment. Likewise, the As levels increased $42 \%$ in lockdown period compared to eleven-year trend. In lockdown period, As presented no correlations with other water quality parameters suggesting its unique source origin in the Santiago River. The elevated concentrations of As have been previously attributed in Santiago river to industrial wastewater discharges (Arellano-Aguilar et al. 2012; Ochoa and Bürkner, 2012; McCulligh and Vega Fregoso, 2019) and even with decreased industrial activities during COVID-19 outbreak, the As levels were higher in this study. The reason may be the low levels of suspended particles during lockdown period that would aid in retention of As in sediments from the above water column through binding or (co)precipitation (Smedley and Kinniburgh, 2002; Rubinos et al. 2003; Barral-Fraga et al. 2020). Similarly, an increased trend of As (42.86\%) with decreased TSS (30.97\%) was observed between lockdown and eleven-year trend. On contrary, a maximum decrease of $24.52 \%$ was noticed in the case of $\mathrm{Pb}$ during lockdown. The sampling stations (11 and 12) located in El Ahogado canal receiving industrial wastewaters from Guadalajara metropolitan area presented higher levels of $\mathrm{Pb}$ with $0.21 \mathrm{mg} / \mathrm{L}$ and $0.19 \mathrm{mg} / \mathrm{L}$ during prelockdown and drastically reduced to $0.014 \mathrm{mg} / \mathrm{L}$ and $0.013 \mathrm{mg} / \mathrm{L}$ in lockdown, reflecting the influence of restricted industrial activities. More supportively, $\mathrm{Pb}$ was positively correlated with industrial pollutants like BOD $\left(r^{2}=0.77\right)$ and $\operatorname{COD}\left(r^{2}=0.83\right)($ Table 3$)$. In addition, 8 out of 13 stations registered sharp reductions ranging from 5-70\% in Pb levels. Likewise, the eleven-year trend when compared with lockdown period revealed 13.78\% reductions in Pb. Furthermore, according to Mexican Standard Norm (2015), the maximum allowable limit for As and $\mathrm{Pb}$ is 0.01 (mg/L). In pre-lockdown, 3 stations displayed As levels above the permissible limits, whereas 6 stations exceeded the limits during lockdown (Fig. 2). The exceedances of $\mathrm{Pb}$ levels were recorded in 9 and 4 stations during prelockdown and lockdown period, respectively. Appraisingly, stations $2-4$ showed higher values $(0.012$ to $0.020 \mathrm{mg} / \mathrm{L})$ than permissible levels in pre-lockdown and fell under the limits $(0.006$ to $0.01 \mathrm{mg} / \mathrm{L})$ during lockdown.

\subsection{Factor analysis}

Factor analysis (FA) was performed on the normalized dataset (12 parameters) analyzed for both pre-lockdown and lockdown period, to understand their compositional pattern, interrelationship between the parameters and identify the factors influencing each one. Three factors contributed for $91.74 \%$ and $84.71 \%$ of the total variance in the dataset of pre-lockdown and lockdown periods. The factor analysis loadings for the study period are presented in Fig. 3a-b. In case of pre-lockdown (Fig. 3a), Factor 1 exhibited strong positive loadings of TSS, BOD, COD, f. coli and t. coli. This factor may be termed as "organic pollution factor" and explained as representing influences from point sources such as industrial effluents and domestic wastewater. The El Ahogado canal (stations 11 and 12) and in the downstream section, Verde River (station 7) and Zula River (station 13) are the main hotspots where the major events of urban and industrial wastewater discharges from NE Guadalajara city and nearby regions occur. Factor 2 had negative 
loadings on $\mathrm{pH}, \mathrm{DO}$ and As. This factor may be termed as "metal pollution factor", and it indicates that $\mathrm{pH}$ and DO seem to favor the enrichment of As in dissolved phase. Finally, EC, turbidity and TN were found in Factor 3 and termed as "inorganic pollution factor" demonstrating their inflow mainly from agricultural and municipal effluents.

When compared to pre-lockdown, the lockdown period showed significant variations in the factor loadings (Fig. 3b). Factor 1 had strong positive loadings of TSS, BOD, COD, TN and Pb. This factor is known as a "mixed pollution factor," and it is defined as a type of mixed pollution that consists of point sources such as industrial wastewater and non-point sources associated with agricultural activities. Factor 2 showed negative loadings for $\mathrm{pH}$ and DO. Unlike in pre-lockdown, Factor 3 termed as "pathogenic pollution factor" presented strong positive loadings for $\mathrm{f}$. coli and t. coli and no associations with other organic pollutants like BOD and COD, clearly reflecting their sources from non-point pollutants like fertilizers, livestock feces, sewage discharges rather than industrial wastewaters. Overall, in FA analysis, the differences observed between pre-lockdown and lockdown evidently demonstrated the positive effects of diminished anthropogenic activities on the water quality parameters. Furthermore, it revealed three main contamination sources in Santiago River as: (1) wastewaters associated to industrial activities; (2) urban wastewaters and sewage discharges; and (3) agricultural effluents.

\subsection{Water quality Index (WQI)}

WQI estimation allows to determine the influence of individual water quality parameter on the overall water quality and its suitability for drinking purpose. In this study, WQI was calculated by considering WHO (2011) and Mexican Standard Norm (2015). The WQI values of the water samples from all the 13 sampling sites for each assessment period are summarized in Table 4. Regardless of the assessment period, the WQI values for water samples from 13 sampling sites ranged from 82.29 to 345.63 and over $97 \%$ of the samples are above 100. The highest WQI value of $230.37,345.63$ and 221.78 was recorded in eleven-year trend, pre-lockdown and lockdown, whereas lowest WQI value was 103.18, 93.71 and 82.29, respectively. Moreover, we observed that the WQI value showed a mixed pattern of change in the water samples of stations between assessment periods (Table 4). For instance, the comparison of WQI values between pre-lockdown and lockdown periods showed improvements in 8 out of 13 stations ranging from $0.78-45 \%$, with an overall change of $4.5 \%$ in the Santiago River indicating positive effect of reduced industrial and commercial activity. Similarly, when WQI values of eleven-year trend were compared, the lockdown period displayed enhancement between $6.2 \%$ and $26.50 \%$ in river waters of majority of stations (11 out of 13), with an overall change of $6 \%$ suggesting short-term improvements of surface water quality along the river. Especially, the sampling stations located in the metropolitan area showed an improvement of $0.65 \%$ and $12.62 \%$ in the lockdown period than pre-lockdown and eleven-year data. The minimal effluent discharge with the temporary shutdown of industrial and commercial activities during the lockdown has likely reduced the level of contamination in the study area. Thus, the assessment of WQI data demonstrates that the river water quality has comparatively been improved in years. Nevertheless, the results also revealed that majority of the river water samples fall under unsuitable water category (WQI $>100$ ), indicating water quality of nearly $90 \%$ of the whole region is greatly deteriorated due to industrialization and various human activities like the inflow of direct sewerage from residential and commercial establishments, lack of proper sanitation system, agricultural run-off, direct disposal of untreated effluents from small scale industries and factories and unabated dumping of solid wastes by the communities residing alongside the river, etc. Although the WQI analysis results unveiled considerable improvements during lockdown period comparably to pre-lockdown and eleven-year trend, the fact about abrupt deterioration and the persistence of pollution for decades in Santiago River cannot be ignored and requires special attention from government authorities. 
Table 4

Summary of WQI values of water samples from 13 sampling sites for each assessment period.

\begin{tabular}{|c|c|c|c|c|c|c|}
\hline Stations & 2009-2019 & Classification & 2019 & Classification & 2020 & Classification \\
\hline 1 & 164.85 & 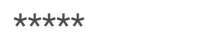 & 105.18 & 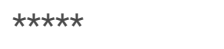 & 126.33 & $\star \star \star \star \star ~$ \\
\hline 2 & 108.69 & 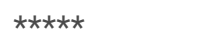 & 94.55 & 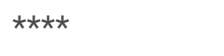 & 82.29 & 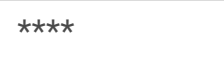 \\
\hline 3 & 114.80 & 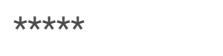 & 93.71 & 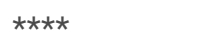 & 84.37 & 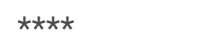 \\
\hline 4 & 124.31 & 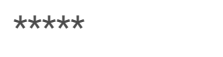 & 114.13 & 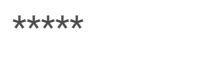 & 118.34 & $\star \star \star \star \star ~$ \\
\hline 5 & 136.71 & 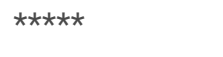 & 121.44 & 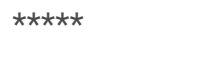 & 100.84 & 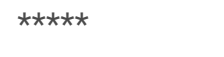 \\
\hline 6 & 147.44 & 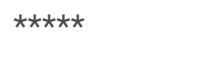 & 144.23 & 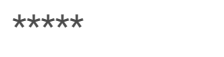 & 143.12 & 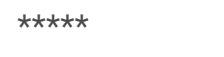 \\
\hline 7 & 184.17 & 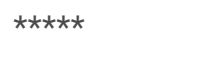 & 159.82 & 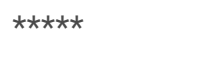 & 194.96 & 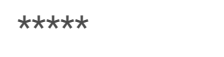 \\
\hline 8 & 176.24 & 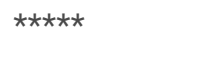 & 141.61 & 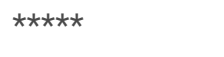 & 138.93 & 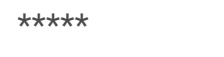 \\
\hline 9 & 103.18 & 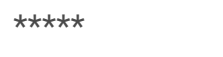 & 100.06 & 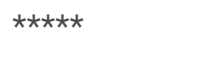 & 116.57 & 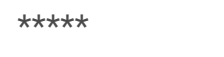 \\
\hline 10 & 134.35 & 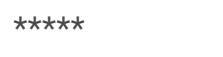 & 178.17 & 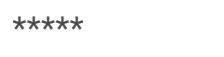 & 173.96 & $\star \star \star \star \star ~$ \\
\hline 11 & 230.37 & 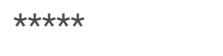 & 345.63 & 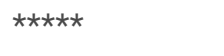 & 190.20 & 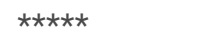 \\
\hline 12 & 164.14 & 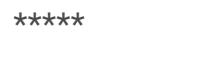 & 186.43 & 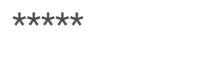 & 221.78 & 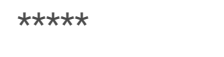 \\
\hline 13 & 149.45 & 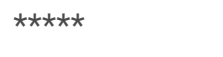 & 97.89 & $\star \star \star \star \star ~$ & 126.77 & 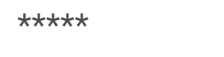 \\
\hline Overall Santiago River & 149.13 & 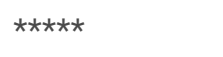 & 144.84 & 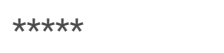 & 139.88 & 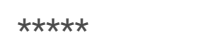 \\
\hline
\end{tabular}

\section{Conclusion}

This study examined data from 13 monitoring stations on 12 characteristics to estimate the impact of two months of COVID-19 lockdown on the water quality of the Santiago River. According to the results, the majority of the river water has been severely polluted, and from an environmental standpoint, the imposition of the lockdown has shed light on the changes and significant improvements on many parameters in this river system. The most notable changes are an increase in WQI values and a significant decrease in BOD, COD, and TSS levels. At the same time, it is worth noting that water quality in the study area has deteriorated alarmingly, owing to human activities, and the main issues are related to organic pollution and coliform count, which have remained at high levels for more than a decade, exceeding the recommended limits. It also pinpointed that the most polluted El Ahogado canal receiving industrial discharges appeared to present potential enhancements due to the temporary closure of the industries closer to the metropolitan area during the lockdown period. These preliminary findings provided a ray of light for a potential recovery of water quality in Santiago River, if the impact of anthropogenic activities is reduced. We believe that the detailed analysis of the industrial closures and discharge flow is necessary in future to acquire in depth insights into designing effective strategies for the suitable management of the water quality in the Santiago River. Moreover, this study will serve as a basis for identifying the possible areas of attention and prioritize regulatory measures throughout the stretch of Santiago River in Mexico.

\section{Declarations}

\section{Ethics approval and consent to participate}

Not applicable.

\section{Consent for publication}

Not applicable.

Availability of data and materials 
The datasets generated and/or analyzed during the current study are available in the CEA Jalisco

(http://www.ceajalisco.gob.mx/contenido/datos_abiertos/).

\section{Conflicts of Interest / Competing Interests}

The authors declare that they have no competing interests.

\section{Funding}

Not applicable.

\section{Author's contribution}

Shruti Venkata Chari - Conceptualization, Methodology, Data curation, Writing - original draft; Gurusamy Kutralam-Munaisamy Conceptualization, Methodology, Data curation, Writing - original draft; Fermín Pérez-Guevara - Methodology, Conceptualization; Ignacio Elizalde Martinez - Supervision.

\section{Acknowledgements}

VCS gratefully acknowledges financial support from DGAPA-UNAM postdoctoral fellowship program, Instituto de Geología, Universidad Nacional Autónoma de México. The authors would like to acknowledge all the doctors, health-care professionals, police personnel, sanitation workers and waste collectors at the frontlines working silently and tirelessly during COVID-19 outbreak worldwide. We also thank CEA-Jalisco for making water quality data open access.

\section{References}

1. Arellano-Aguilar, O., Ortega Elorza, L., \& Gesundheit Montero, P., (2012). Estudio de la contaminación en la cuenca del río Santiago y la Salud Pública en la región. Greenpeace. México, DF

2. Barral-Fraga, L., Barral, M.T., MacNeill, K.L., Martiñá-Prieto, D., Morin, S., Rodríguez-Castro, M.C., Tuulaikhuu, B.A., \& Guasch, H., (2020). Biotic and Abiotic Factors Influencing Arsenic Biogeochemistry and Toxicity in Fluvial Ecosystems: A Review. Int J Environ Res Public Health 17(7):2331

3. Brown RM, McClelland NI, Deininger RA, Tozer RG (1970) Water quality index-do we dare? Water Sewage Works 117(10):339-343

4. Chowdhury RM, Muntasir SY, Monowar HM (2012) Water Quality Index of Water Bodies Along Faridpur-Barisal Road in Bangladesh. Global Eng Technol Rev 2 (3)

5. Cude C (2001) Oregon Water Quality Index: A tool for evaluating water quality management effectiveness. J Am Water Res Assoc $37: 125-137$

6. Dutta V, Dubey D, Kumar S (2020) Cleaning the River Ganga: Impact of lockdown on water quality and future implications on river rejuvenation strategies. Sci Total Environ 743:140756

7. Ewaid SH, Abed SA (2017) Water quality index for Al-Gharraf river, southern Iraq. Egypt J Aquat Res 43(2):117-122

8. Ferrari L, Orozco-Esquivel T, Manea V, Manea M (2012) The dynamic history of the Trans-Mexican Volcanic Belt and the Mexico subduction zone. Tectonophysics 522:122-149

9. Gautam S (2020) COVID-19: air pollution remains low as people stay at home. Air Qual Atmos Health 13:853-857

10. GDF (2020) Nuevas medidas para la fase 3 por COVID-9. https://wwwcdmxgobmx/portal/articulo/nuevas-medidas-para-la-fase3-por-covid-9

11. Horton RK (1965) An index number system for rating water quality. J Walter Poll Cont Fed 37(3):300-306

12. INEGI (2014) Meteorological datasets of Mexico (1951-2014).

http://www.inegi.org.mx/geo/contenidos/recnat/clima/infoescala.aspx

13. INEGI (2015) Population dataset of Mexico. http://cuentame.inegi.org.mx/monografias/informacion/jal/poblacion/default.aspx? tema $=\mathrm{me} \% 26 \mathrm{e}=14$

14. Kutralam-Muniasamy G, Pérez-Guevara F, Roy PD, Elizalde-Martínez I, Shruti VC (2020) Impacts of the COVID-19 lockdown on air quality and its association with human mortality trends in megapolis Mexico City. Air Qual Atmos Health 1-10 
15. McCulligh C, Páez-Vieyra JC, Moya-García G (2007) Mártires del Río Santiago: informe sobre las violaciones al derecho a la salud ya un medio ambiente sano en Juanacatlán y El Salto, Jalisco, México

16. McCulligh C, Vega Fregoso G (2019) Defiance from Down River: Deflection and Dispute in the Urban-Industrial Metabolism of Pollution in Guadalajara. Sustainability 11(22):6294

17. Mexican Standard Norm (2015) Norma Oficial Mexicana NOM201-SSA1-2015, Productos y servicios. Agua y hielo para consumo humano, envasados y a granel. Especificaciones sanitarias. http://dof.gob.mx/nota_detalle.php? codigo $=5420977 \&$ fecha $=22 / 12 / 2015$

18. Mexico Health Ministry (2020) Nuevo Coronavirus en el mundo COVID-19 Comunicado Técnico Diario. https://wwwgobmx/salud/prensa/nuevo-coronavirus-en-el-mundo-covid-19-comunicado-tecnico-diario-236595

19. Nakada LYK, Urban RC (2020) COVID-19 pandemic: Impacts on the air quality during the partial lockdown in São Paulo state, Brazil. Sci Total Environ 139087

20. Ochoa H, Bürkner HJ (2012) Gobernanza y gestión del agua en el Occidente de México: la metrópoli de Guadalajara. ITESO University

21. Otmani A, Benchrif A, Tahri M, Bounakhla M, El Bouch M, Krombi MH (2020) Impact of Covid-19 lockdown on PM10, SO2 and NO2 concentrations in Salé City (Morocco). Sci Total Environ 139541

22. Patel PP, Mondal S, Ghosh KG (2020) Some respite for India's dirtiest river? Examining the Yamuna's water quality at Delhi during the COVID-19 lockdown period. Sci Total Environ 744:140851

23. Rizo-Decelis LD, Andreo B (2016) Water quality assessment of the Santiago River and attenuation capacity of pollutants downstream Guadalajara City, Mexico. River Res Appl 32(7):1505-1516

24. Rodríguez-Tapia L, Morales-Novelo JA (2017) Bacterial pollution in river waters and gastrointestinal diseases. International journal of environmental research and public health 14(5):479

25. Rubinos D, Barral MT, Ruiz B, Ruiz M, Rial ME, Álvarez M, Díaz-Fierros F (2003) Phosphate and arsenate retention in sediments of the Anllóns river (northwest Spain). Water Sci Technol 48(10):159-166

26. Saadat S, Rawtani D, Hussain CM (2020) Environmental perspective of COVID-19. Sci Total Environ 138870

27. Selvam S, Jesuraja K, Venkatramanan S, Chung SY, Roy PD, Muthukumar P, Kumar M (2020) Imprints of pandemic lockdown on subsurface water quality in the coastal industrial city of Tuticorin, south India: A revival perspective. Sci Total Environ 139848

28. Seo M, Lee H, Kim Y (2019) Relationship between Coliform Bacteria and Water Quality Factors at Weir Stations in the Nakdong River, South Korea. Water 11(6):1171

29. Smedley PL, Kinniburgh DG (2002) A review of the source, behaviour and distribution of arsenic in natural waters. App Geochem 17(5):517-568

30. Susilowati S, Sutrisno J, Masykuri M, Maridi M (2018) Dynamics and factors that affects DO-BOD concentrations of Madiun River. In AIP Conference Proceedings (Vol. 2049, No. 1, 020052). AIP Publishing LLC

31. Tripaty JK, Sahu KC (2005) Seasonal hydrochemistry of groundwater in the barrier spit system of the Chilika Lagoon, India. J Environ Hydro 13:1-9

32. Von Bertrab E (2003) Guadalajara's water crisis and the fate of Lake Chapala: A reflection of poor water management in Mexico. Environ Urban 15(2):127-140

33. WHO (2011) Guidelines for Drinking Water Quality, 4th Ed. Available: http://www.who.int/water

34. WHO (2020) https://wwwwhoint/emergencies/diseases/novelcoronavirus-2019

35. Yunus AP, Masago Y, Hijioka Y (2020) COVID-19 and surface water quality: Improved lake water quality during the lockdown. Sci Total Environ 139012

\section{Figures}




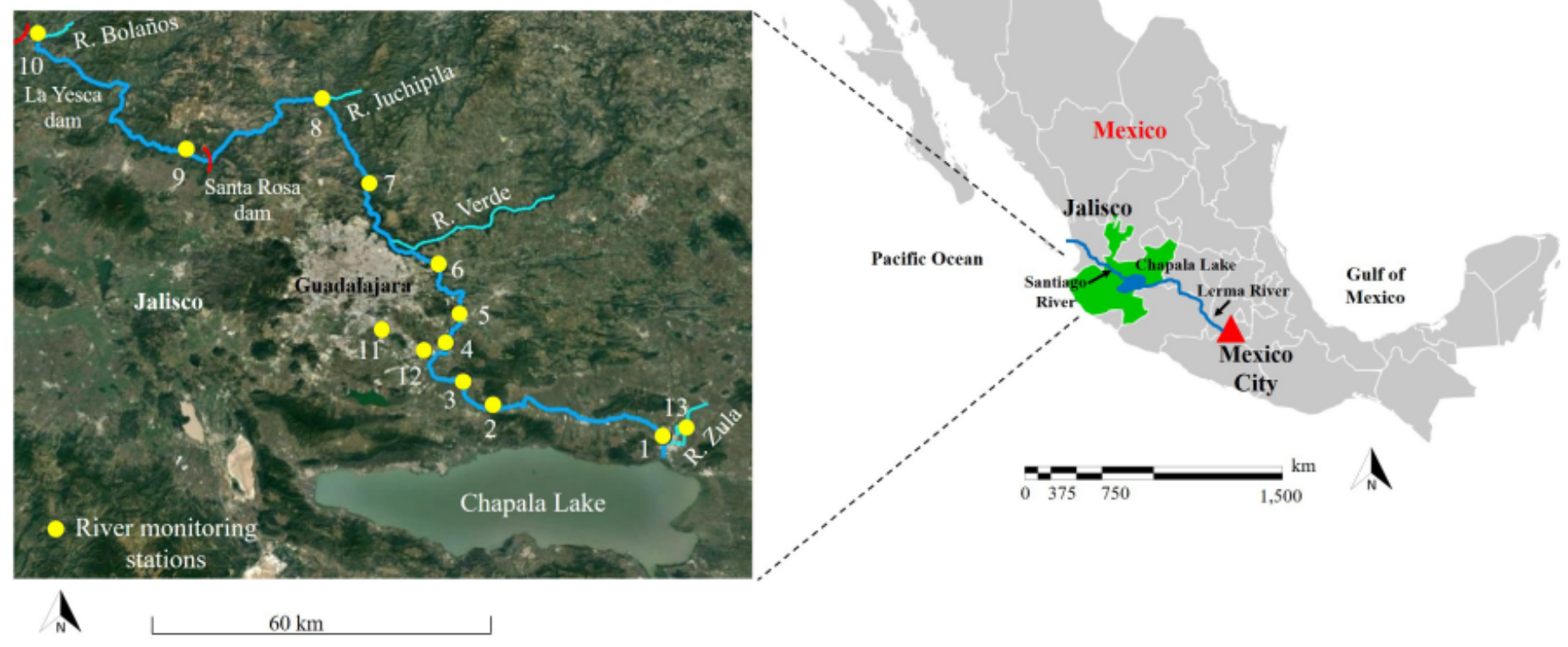

\section{Figure 1}

Study area map showing all the 13 sampling locations along the Santiago River, Jalisco (Mexico). 


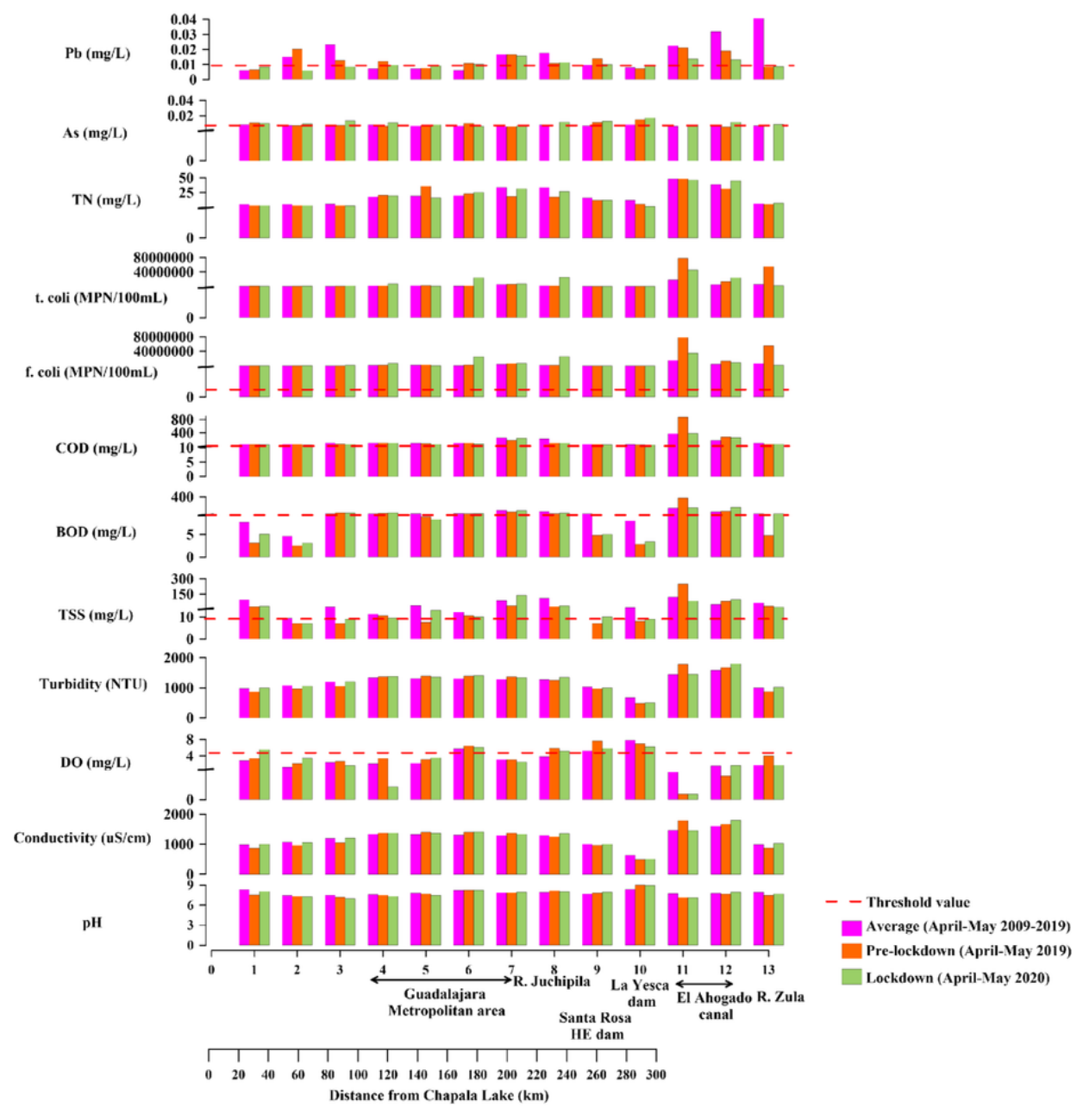

Figure 2

Trend in the observed concentration values of 12 water quality parameters during pre-lockdown, lockdown and 2009-2019 in Santiago River at different locations. 


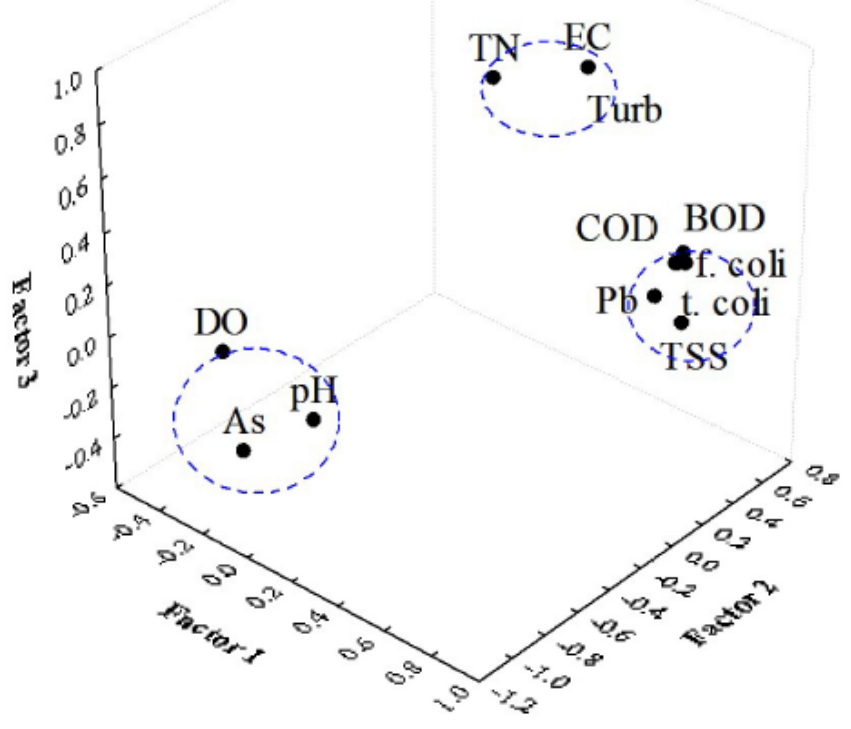

(a)

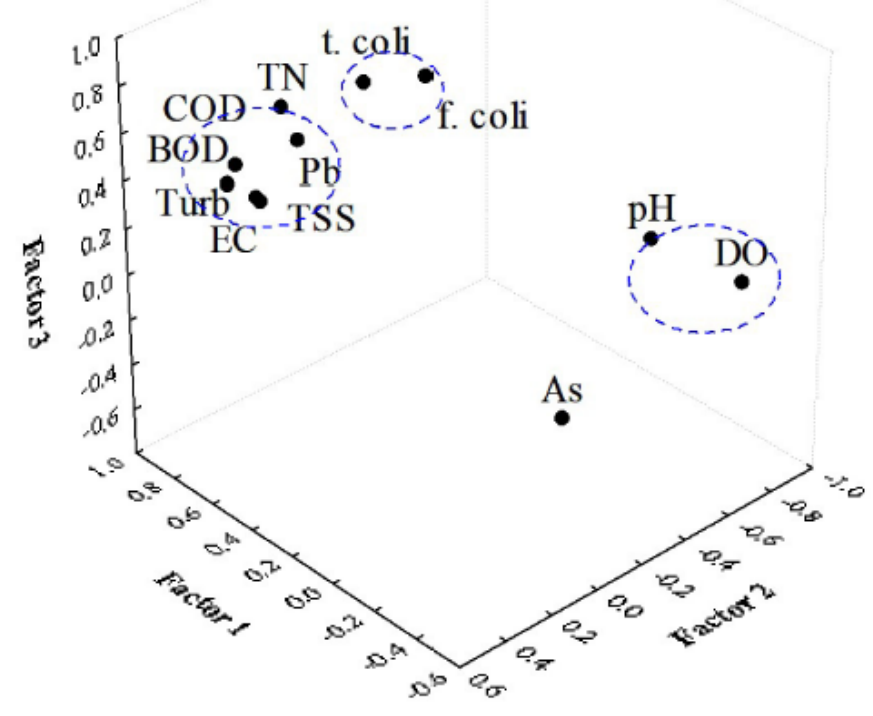

(b)

Figure 3

Factor analyses loading (a) pre-lockdown and (b) lockdown.

\section{Supplementary Files}

This is a list of supplementary files associated with this preprint. Click to download.

- GA.pdf 